\title{
Smart cities and the pandemic: digital technologies on the urban management of Brazilian cities
}

\author{
Tharsila Maynardes Dallabona Fariniuk 12
}

1 Pontifícia Universidade Católica do Paraná, Curitiba / PR - Brazil

${ }^{2}$ Centro Universitário Unifacear / Curso de Arquitetura e Urbanismo, Curitiba / PR - Brazil

COVID-19 has been affecting the way of life in cities. The pandemic curve grows significantly in some countries, such as Brazil, requiring rapid responses from the public administration. This research, conducted in April 2020, characterizes the use of digital tools in adapting Brazilian cities to the pandemic in light of the concept of smart cities, presenting a panorama of the current situation. The results indicated that $83 \%$ of the cities surveyed used digital tools in measures to fight the pandemic, such as increasing social distancing and adapting public services. The concentration of initiatives tends to follow the geographic distribution of confirmed cases, i.e., digital tools are more used in places where the pandemic curve is more accentuated. Also, cities that are historically more open to innovation demonstrated a heavier use of digital technologies and strategies to fight the pandemic. Finally, the results indicate that the largest Brazilian cities follow, at some level, the trends of digital optimization observed worldwide. Keywords: COVID-19; smart cities; digital technologies; public management.

\section{Smart cities e pandemia: tecnologias digitais na gestão pública de cidades brasileiras}

A pandemia da COVID-19 vem afetando o modo de vida nas cidades. Em alguns países - como o Brasil - a curva epidemiológica cresce significativamente, exigindo respostas rápidas da administração pública. Esta pesquisa, conduzida em abril de 2020, visa caracterizar a utilização de ferramentas digitais na adaptação das cidades brasileiras à pandemia, baseada no conceito de smart city. Para tanto, buscou-se traçar um panorama da adoção de ferramentas digitais pela administração pública nas cem maiores cidades brasileiras, como resposta aos desafios impostos pela situação pandêmica, contribuindo para efetivar o isolamento ou para adaptar o funcionamento de atividades. Os resultados indicam a aplicação de tais estratégias em $83 \%$ das cidades pesquisadas, segundo a distribuição geográfica de casos da doença confirmados. A concentração das iniciativas sugere que a adoção da tecnologia acompanha a previsão da curva de infecção, e aponta para a tendência de adoção das estratégias em locais de contexto historicamente favorável à inovação. Característica fundamental das cidades inteligentes, o recurso à tecnologia digital na otimização dos serviços indica que as cidades pesquisadas estão, em algum nível, seguindo uma tendência mundial.

Palavras-chave: COVID-19; smart cities; tecnologias digitais; gestão pública.

\section{Smart cities y pandemia: tecnologías digitales en la gestión pública de ciudades brasileñas}

La pandemia de COVID-19 ha estado afectando la forma de vida en las ciudades. En algunos países -como Brasilla curva epidemiológica crece significativamente, lo que requiere respuestas rápidas de la administración pública. Esta investigación, realizada en abril de 2020, tiene como objetivo caracterizar el uso de herramientas digitales en la adaptación de las ciudades brasileñas a la pandemia, a la luz del concepto de ciudad inteligente. Para ello, buscamos esbozar un panorama de la adopción de estas herramientas por parte de la administración pública en las cien ciudades brasileñas más grandes, como una forma de responder a los desafíos impuestos por la situación de pandemia, contribuyendo a efectuar el aislamiento o adaptar el desempeño de las actividades. Los resultados indicaron la presencia de tales estrategias en el $83 \%$ de las ciudades encuestadas. La concentración de las iniciativas sugiere que la adopción de la tecnología sigue el pronóstico de la curva de infección, y señala la tendencia a adoptar estrategias en lugares con un contexto históricamente favorable a la innovación. Característica fundamental de las ciudades inteligentes, el uso de tecnología digital en la optimización de los servicios indica que las ciudades encuestadas están siguiendo, en algún nivel, una tendencia mundial.

Palabras clave: COVID-19; smart cities; tecnologías digitales; gestión pública. 


\section{INTRODUCTION}

The advancements of Information and Communications Technologies, increasingly smaller in size and more sophisticated, have been altering urban relations. Simultaneously, such technologies are potentially capable of widening the recognition of urban problems, which are often invisible. This regards what Amin and Thrift (2002, p. 8) refer to as "a new urbanism", in which the man-machine relationship translates the growing complexity of urban areas.

The term smart city has emerged more recently as a relevant definition for this process. Although there is no consensus around the concept (Angelidou, 2014; Albino, Berardi, \& Dangelico, 2015; AlDairi \& Tawalbeh, 2017; Bibri \& Krogstie, 2017; Cassandras, 2016), the term is commonly employed to define cities which utilize digital tools with the purpose of automatizing systems and services (AlDairi \& Tawalbeh, 2017; Llacuna, Colomer-llinàs, \& Meléndez-Frigola, 2015), with an emphasis on sustainability, sensing and collaboration (Abella et al., 2015), and the goal of optimizing resources and precision in the supply of public services (Salgado, 2016). Other factors, such as urban resilience, adaptability and government capacity are also taken into consideration in the concept. These characteristics have recently resurfaced once more, when a particular situation put the structuring of cities to the test: the COVID-19 pandemic.

Initially identified in China in 2019, the pandemic has been affecting the way of life in cities in a global scale. Up to the writing of this paper (April 2020) the number of confirmed cases had reached more than 3.2 million worldwide (TradingView, as cited by the World Health Organization [WHO], 2020). In some countries a decline in the numbers of cases and deaths may already be observed, while in others the curve has been growing significantly - such is the case of Brazil -, demanding rapid responses from the public management.

Sakellarides (2020) remarks that, as the decline of the pandemic curve is observed, it is necessary to take the victories as an opportunity to consolidate public policies and administrative actions. The author affirms it is necessary to pursue the implementation of community intelligence, especially in regards to an enhanced interconnectivity which assists the monitoring and interpretation of healthrelated data. Furthermore, the opportunity of data treatment in situations such as the current one reveals there is a lot of room for reflection on human behavior in the face of rearranging mobilities, presence and connections between individuals (Oliver et al., 2020).

This is the guiding context of this research, out of which several questions emerge: may the concept of smart city, understood as the enhancement of management through digital tools and information fluxes, among other factors, be seen in the actions oriented towards adaptation to the pandemic situation? Which current Brazilian practices may suggest the manifestation of the phenomenon of urban spaces and smarter governance, translated in the understanding of people in management about the potential of technology in articulating urban resilience?

Thus, the objective of this research is to characterize the use of digital tools in the adaptation of Brazilian cities to the pandemic situation of COVID-19, in light of the concept of smart cities. The discussion revolves around two antithetical hypotheses: a) the adoption of technology has followed - or even preceded - the predicted growth of the infection curve, which would be reflective of a fundamental aspect of smart cities: the response from public management with the use of technologies as tools for strengthening resilience; and b) the adoption of technology has not served to anticipate 
the occurrences, but actually consisted of a response, a posteriori, to the rise of the infection curves in the cities. In this case, the speed of the response would be explained by the immediacy-led demands of the faced situation.

In this investigation, an overview of the adoption of digital tools by public management as a way of responding to certain challenges imposed by the situation is outlined: namely the challenges of implementing isolation and the adaptation of activities. The overview was delineated through the data survey from the hundred biggest Brazilian cities.

This research originates from a series of previous studies regarding the phenomenological construction of the concept of smart cities in Brazil. An authorial methodology developed in a study carried out between the years of 2014 and 2018, adapted to the subject matter of the pandemic, is utilized. It consists of a preliminary version of a research which is intended to be expanded, due to its novelty in the field of contemporary urban planning and the recurring changes to the situation in Brazil.

\section{SMART CITIES AND BIG DATA IN RESPONSE TO CRITICAL SITUATIONS}

Calvino, in his renowned work Le città invisibili (2002), observes that what is in fact taken from cities are not their wonders, but their capacity to respond to problems. Anthopoulos (2017) adds to this argument affirming that a city may be assumed smart if it effectively meets local demands, even when technology is not imperative.

Sakellarides (2020) comments that, in the time of COVID-19, smart cities articulate two complementary frames of mind. One is that in which the emergency decisions in the areas of health and epidemiology, where success fundamentally relies on the adherence to established norms, become regulations. The other refers to the collaborative and collective intelligence (as in the concept by Lévy, 2003), formed by the creative community sharing knowledge in order to accelerate learning and adaptation to the lived situation. According to the author, in times like these, being a smart community means a swift adaptation which takes advantage of the digital potential and availability of data.

Data mining for decision-making ends is another attribute of smart cities as well, and it has a special meaning in the pandemic situation. Barns (2016) argues that data management contributes to the speed of responses to challenges from the public governance. Data, in this sense, are mechanisms potentially capable of promoting integration between the sectors, even if such integration is "forced" by the emergency situation.

The use of digitized information is, for Oliver et al. (2020), a potential tool in dealing with the pandemic, considering the ease of disseminating information between the population via mobile telephony. The authors point to four extents to which this contribution may occur: a) situational awareness, in which public administration and the population may better comprehend the trends based on previously ignored or invisible information; b) a cause and effect relationship of the measures taken, in a gauge which unveils which variables make a difference and which cause problems; c) predictability, made possible in virtue of the real-time aspect of Big Data, useful for defining actions, opportunities, risks and demands; d) impact assessment, which allows the observation of where the obstacles which hinder the success of actions are.

Inn (2020), in the same line of thought, affirms that the scope of smart cities' actions in the face of the pandemic is also revealed, apart from the cited areas, in the use of artificial intelligence for 
monitoring and urban public security, with the use of drones which facilitate mobility and surveillance actions, research technologies, and emerging platforms which help virtual communication such as chats and application programs.

\section{METHODOLOGY}

For the purpose of outlining the panorama of the digital tooling used as a response from the public administration in Brazilian cities to the pandemic situation, a survey was carried out in the hundred largest cities of the country. In selecting the cities, the populational aspect, based on the projection from the Brazilian Institute of Geography and Statistics for 2019 (IBGE), was considered. The choice of considering the biggest cities takes into consideration the principle of Rolnik and Solmekh (2002), who affirm that big urban areas potentialize problems of territorial management - which indicates, for the intents of this study, the representativeness of the chosen cities. Therefore, by studying cities with higher population densities, an understanding in a panoramic and macro-scale of the way in which city administrations deal with the pandemic situation is expected.

The data collection took place between April 20 and April 28, 2020, consulting with three sources, in order of priority: city hall websites, media outlets and the city halls' social media. The search for initiatives with the use of the digital tooling was carried out through the combination of keywords, namely: "name of the city", "COVID-19", "technology", "digital", "virtual" and "smart city", also searched for in their respective plural forms and combined with each other through the use of Boolean operators. Only the results officially publicized by the city hall and which necessarily involved decision-making from the public administration were selected. In this research were considered as the corpus of work the initiatives which employ the technological tooling of support to the pandemic situation, in accordance to the definition of Inn (2020): monitoring and surveillance (such as cameras and drones), digital platforms and communication tools (application programs and chats).

The searched data - chiefly news - fed a spreadsheet to the saturation of incidences. In the formatting of the spreadsheet, the initiatives were classified by the purposes of using the digital tool. This classification determined a keyword for each incidence, which culminated, lastly, in a categorization of twenty typologies of analysis. The attribution of categories arose from the description of the news, following the methodological resources for content analysis of Moraes (1999), which are as follows: a) unitarization of the information into parts for analysis; b) classification of units into categories; c) description and analysis of the categories.

Firstly, the data analysis considered the quantitative character of the adoption of digital tools; secondly, the qualitative character was considered, in light of the concept of smart cities. In order to deepen the analysis, the geographic distribution was considered, in comparison to two data sets of context: a) the city's acknowledgment of the adoption of technological tools, indicative of a previous history of digital strategies-based governance; and b) the city's GDP per capita. The first data set was obtained from the Connected Smart Cities index (2019), which has been developing yearly research into urban intelligence in the 666 Brazilian cities with over 50.000 inhabitants since 2014. The index provides a general classification of smart cities, which it categorizes into thematic axes (from which this research fits into "technology and innovation"), based on the research with 70 indicators converging with other international publications. The second data set - GDP per capita - was obtained from the survey conducted by IBGE, the more recent results of which date back to 2017. 


\section{RESULTS}

The results have indicated the adoption of the digital tooling in $83 \%$ of the researched cities. It is worth noting, in this particular case, the probability of distortion (for the absence or under-notification of cases) even when there was no publicizing of the initiatives in the researched media. A total of 198 different digital strategies have been accounted for, including the grouping of several of them in certain cities.

Figure 1 presents the geographic distribution of the results, indicating a higher density in the Brazilian capitals and metropolises, especially in the states of São Paulo, Rio de Janeiro, Paraná and Distrito Federal. Figure 2 presents the distribution of confirmed cases of the virus according to information from the Ministry of Health (2020). The comparison between the two situations suggests a tendency of utilizing the digital tooling as a strategy to deal with the pandemic precisely in the most affected areas.

A brief analysis through the method of Pearson measures the degree of relationship between the variables under consideration by the interval -1 and +1 . The closer to 1 , the larger the positive correlation between them (Figueiredo \& Silva, 2009). Thus, measuring the number of digital strategies found in each Brazilian state with the data of confirmed cases and number of deaths (Ministry of Health, 2020) we found, respectively, correlations of 0,8286 and 0,8347 , which can be regarded as high rates. This statistical methodology is valid for rates of normal distribution, which may present a certain fragility in this case, given that the numbers vary on a daily basis and do not necessarily follow a constant curve. However, at first the numbers and distribution on the map seem to suggest a proximity with the "a" hypothesis mentioned previously: the adoption of technology has followed - or even preceded - the predicted growth of the infection curve. Nonetheless, it is worrisome to notice the low incidence of initiatives publicized by the Northern and part of the Northeastern areas, where the occurrence of confirmed cases is alarming. This may be linked to several different factors, among which are the problems of under-notification of cases and the issues relative to digital exclusion - a reality in many areas of the country. To deepen this discussion, other parameters have to be included, such as those that follow.

\section{FIGURE 1 DISTRIBUTION OF FOUND RESULTS}

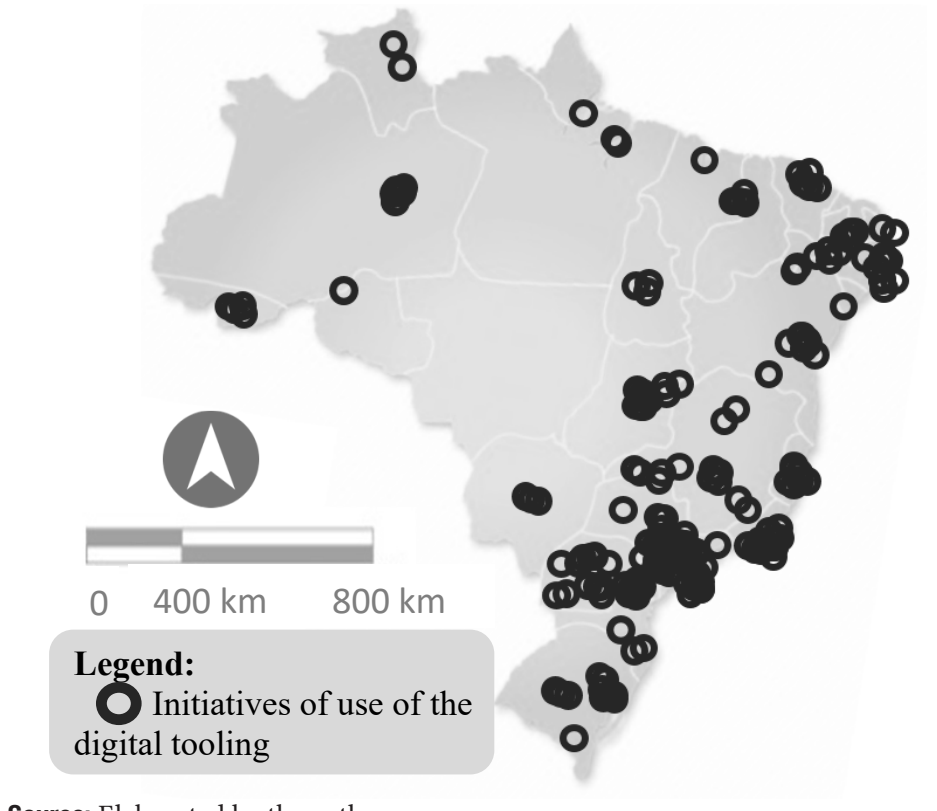

Source: Elaborated by the author. 


\section{FIGURE 2 MAPPING OF CONFIRMED COVID-19 CASES IN APRIL 2020}

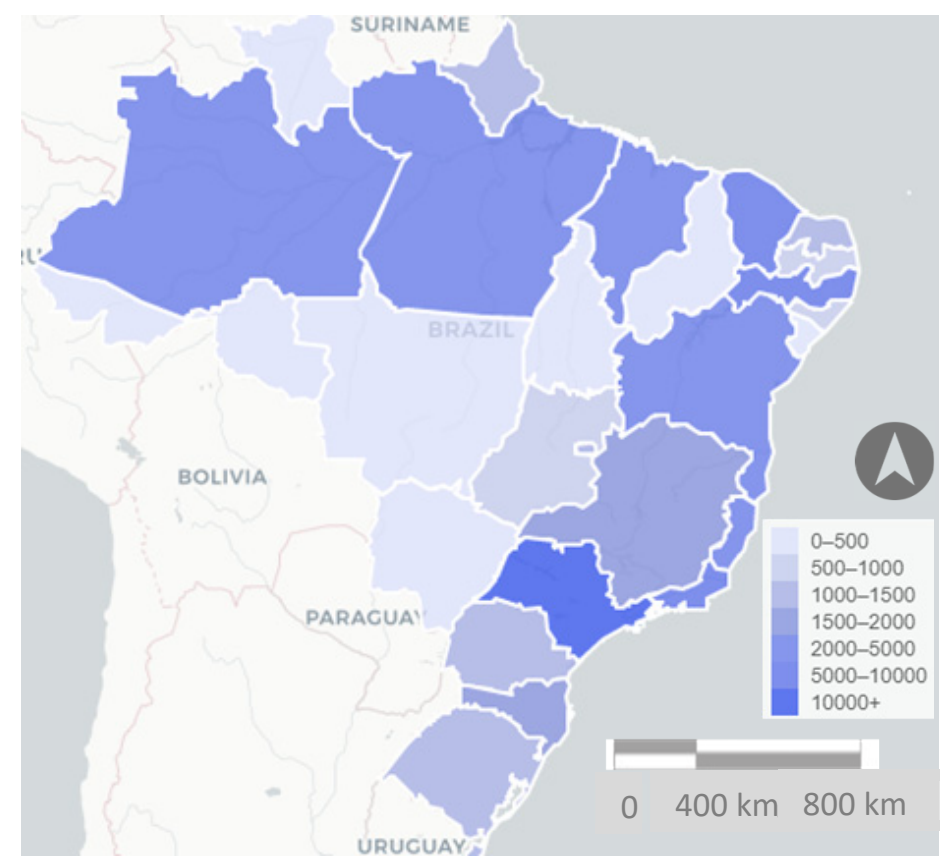

Source: Ministry of Health (2020) on April 29th, 2020, based on data provided by the Health Secretariats.

The process of analysing the 198 strategies through the descriptive units led to their classification into ten categories, as presented in Box 1.

\section{BOX 1}

\section{DESCRIPTIONS OF THE TEN CATEGORIES OF RESULTS}

\begin{tabular}{ll} 
Category & Description \\
$\begin{array}{l}\text { Distance learning/training } \\
\text { Virtualization of the classes from the municipal network / Distance learning training courses for } \\
\text { public servers and teachers. }\end{array}$ \\
$\begin{array}{l}\text { Digital tools of support to } \\
\text { hospitals/health }\end{array}$ & $\begin{array}{l}\text { Teleconsultations / Tools for online scheduling of consultations and vaccines / Virtual visits of } \\
\text { infected patients / Virtual psychological support platforms / Mapping of confirmed cases. }\end{array}$ \\
$\begin{array}{l}\text { Reinforcement of } \\
\text { information to the }\end{array}$ & $\begin{array}{l}\text { Information sharing through digital tools, such as: sending SMS, application programs } \\
\text { population through digital } \\
\text { means }\end{array}$ \\
$\begin{array}{l}\text { Cultural dissemination } \\
\text { through digital means }\end{array}$ & $\begin{array}{l}\text { Municipal incentive to local artists / Online cultural activities / Incentivo municipal a artistas } \\
\text { locais / Atividades culturais online / Online cultural promoting in lieu of face-to-face events. } \\
\text { Call center developed specifically for the situation (doubts, protocols, information), or the } \\
\text { Telephone exchange }\end{array}$ \\
\hline
\end{tabular}




\begin{tabular}{|c|c|}
\hline Category & Description \\
\hline $\begin{array}{l}\text { Incentives to the local } \\
\text { economy through digital } \\
\text { means }\end{array}$ & $\begin{array}{l}\text { Development of the local economy (producers and artisans) by means of virtual dissemination / } \\
\text { Transposition of open markets to a virtual environment / Tax incentives and aid to the local } \\
\text { economy / Actions to strengthen local entrepreneurship. }\end{array}$ \\
\hline $\begin{array}{l}\text { Monitoring of } \\
\text { agglomerations through } \\
\text { geolocation data }\end{array}$ & $\begin{array}{l}\text { Inspection of agglomeration outbreaks via geolocation data obtained through smartphone data / } \\
\text { Surveillance through cameras. }\end{array}$ \\
\hline Municipal services & Transposition of municipal services and protocols to virtual platforms. \\
\hline Online tax assistance & $\begin{array}{l}\text { Transposition of municipal tax assistance to virtual mode / simplification of tax protocols in } \\
\text { virtual medium. }\end{array}$ \\
\hline Hackathon & Event proposing innovative solutions for the pandemic situation. \\
\hline
\end{tabular}

Source: Elaborated by the author.

It may be observed that several cities make use of the digital tool for the transposition of activities previously realized only presentially (such as local markets, cultural events and municipal service protocols). This suggests that the strategy is not exactly serving to optimize a public administration activity, but only the digitization of processes. Although this action aims to intensify the isolation measures, it may also point to a more elementary approach to the use of the technological potential, which may be largely justified by the low cost of the transposition from analog to digital in relation to other improvements. Graham and Marvin (1996) characterize the simple replacement of the physical for the digital as the most "shallow" level of the technological impact in the medium. This piece of data may partially confirm the second hypothesis, which indicates not necessarily an anticipation, but an a posteriori action as a response to the critical need.

It is also worth calling attention to the incidence of strategies via telephone exchange, which seems to be anachronistic in comparison to the digital devices. Nevertheless, a quick clarification by telephone may momentarily produce a state of trust and comfort in the citizen, who is inevitably disturbed by the stress and anxiety which characterize situations such as the current one.

In contrast, the type of action that uses data from smartphones for monitoring urban agglomerations is the subject of antagonistic discussions: on the one hand, the speed in obtaining accurate data through geolocation, characteristic of smart cities, and the use of Big Data for information distribution and guidance for public administrators (Lemos, 2013); on the other hand, the concern with privacy and the protection of identities, an aspect which several researchers consider as a fundamental guideline for the measurement of the urban intelligence project (Aldairi \& Tawalbeh, 2017).

Among these categories, the highest incidence is that of the use of digital tools as educational support, for the purpose of maintaining social isolation without prejudice to students from the municipal network (see Figure 3). Secondly, there are the virtual strategies in the area of health and support to the hospital system, with a special emphasis on teleconsultations, which avoid - at least initially - the agglomeration of patients in care units. It is also worth noting the initiatives to reinforce information through virtual means, especially by the means of application programs or platforms developed exclusively for this purpose. 


\section{FIGURE 3 INCIDENCE OF STRATEGIES, BY CATEGORY}

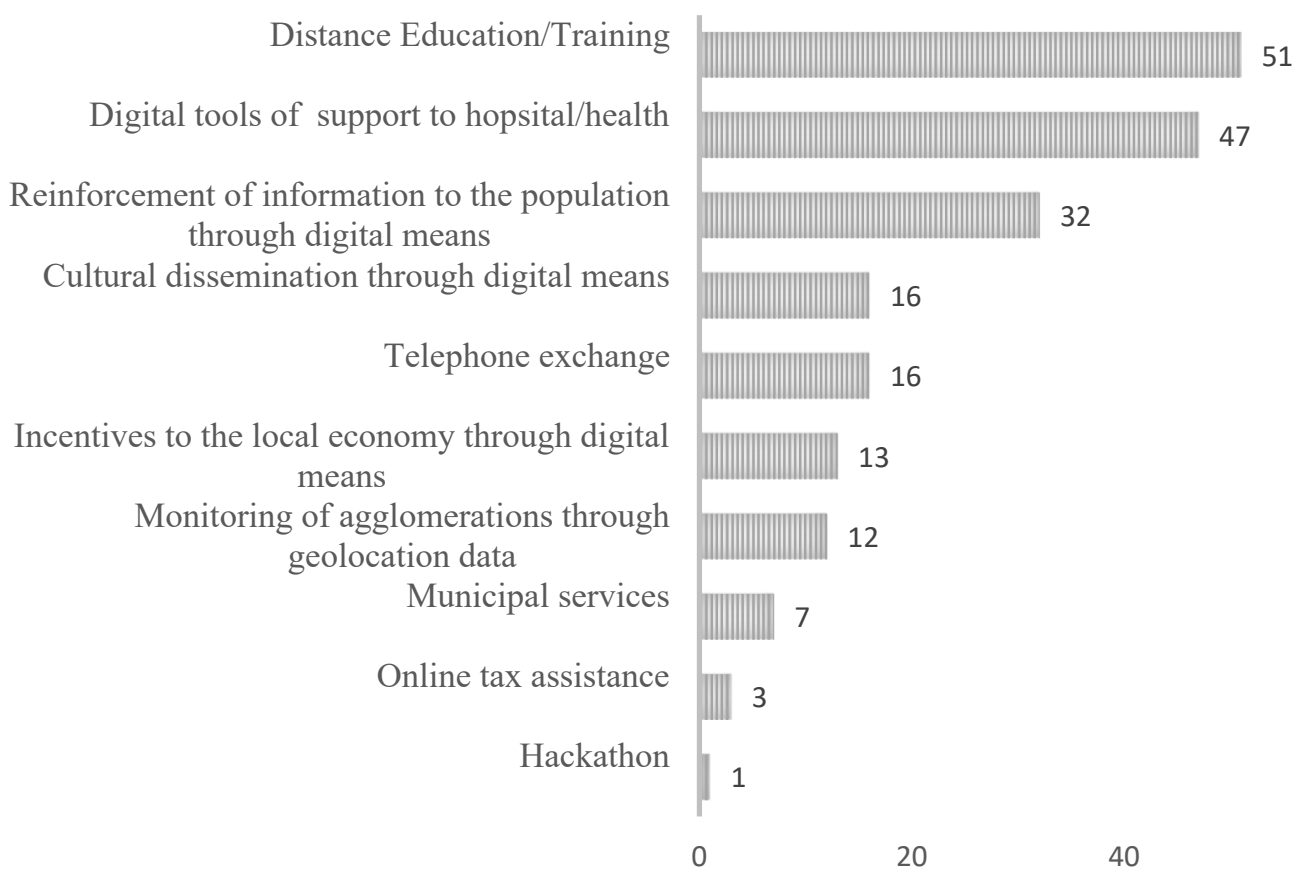

Source: Elaborated by the author.

The confirmation, or lack thereof, of each of the two hypotheses - urban intelligence by anticipation of demand versus response to the worsening situation - requires a deepening of contextual issues. Hence the comparison between the geographic distribution of the surveyed initiatives and the socioeconomic structural factors, such as GDP distribution, with the history of adopting the digital tooling in the cities. Figure 4 presents this comparison.

Image (b), which presents the geographic distribution of cities known for their history of adopting technology and innovation (data from 2019), shows an equivalent tendency to map (a), wherein the surveyed initiatives are arranged. This partially contributes to the examination of the two raised hypotheses. The history of utilizing the technological tooling, besides indicating a pre-existing infrastructure, strengthens the municipal scope of learning and experience, and facilitates new urban intelligence processes through technology. This analysis, therefore, guides the reflection towards a middle ground between the previously presented hypotheses, considering both simultaneously, as complementary to each other. This occurs due to the analysis suggesting the possibility of anticipating demands, on the part of the cities which already have successful experiences with the adoption of Information and Communications Technologies (ICTs) and have validated their methods in order to build confidence for new processes; at the same time it also allows the initiatives surveyed here to correspond only to the emergency responses to demands, since the infrastructure is already consolidated.

This analysis, however, may still be amplified into new discussions. When observing the (c) portion of the image, the Brazilian municipal distribution of GDP per capita, which will serve as basis for 
this new reflection, is noticeable. The map shows, according to the GDP, a higher concentration of wealth in the Southern, Southeastern and part of the Midwestern areas, as well as a few locations in the Northeastern and Northern areas (especially capitals and metropolitan areas). Such distribution, in comparison to the disposition of the surveyed initiatives, also suggests a tendency towards adopting digital tools in places with some socio-economic development - an aspect which could be expanded on through discussions about income distribution, regional production scales, schooling and access to education.

(a)

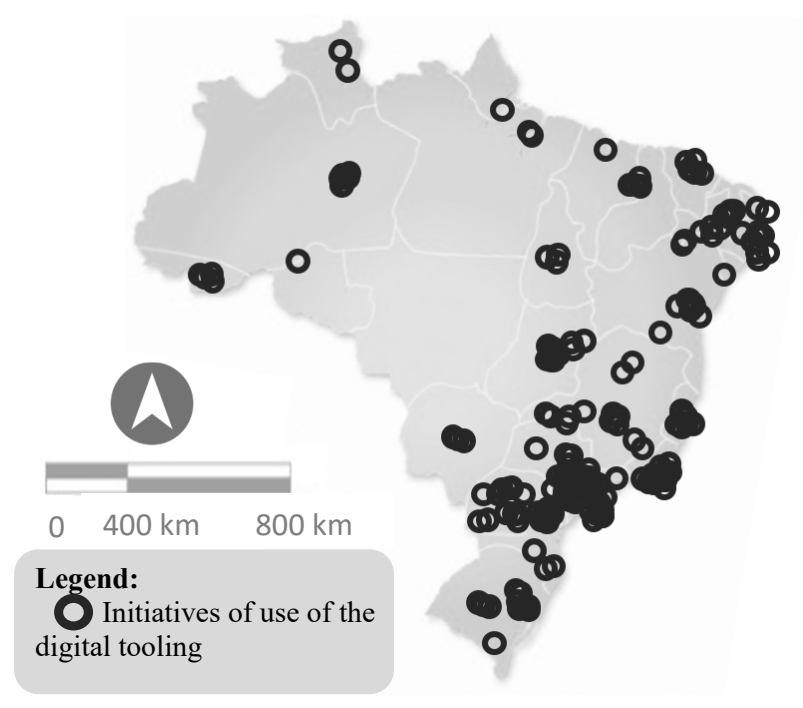

Source: Elaborated by the author.

(b)

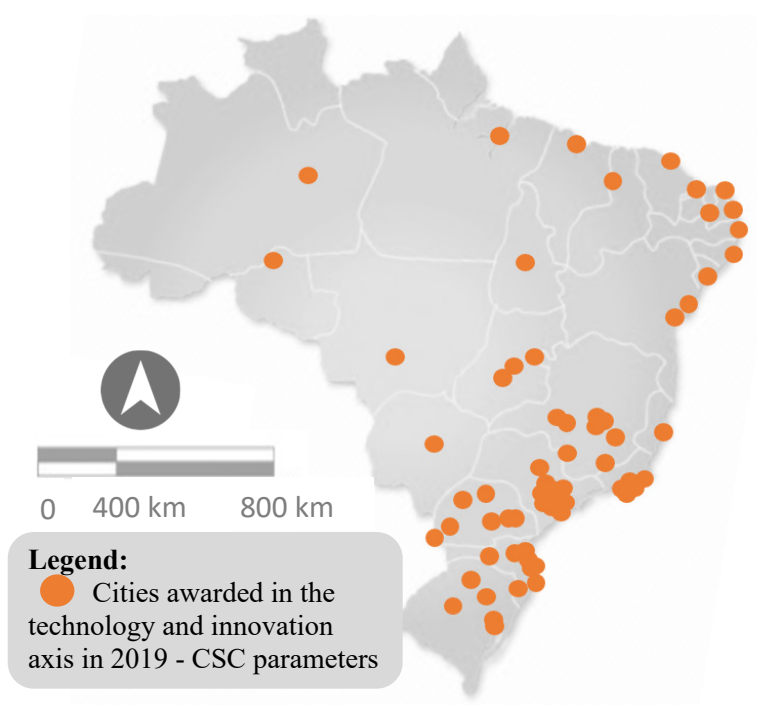

Source: Elaborated by the author based on Connected Smart Cities (2019). 
(c)

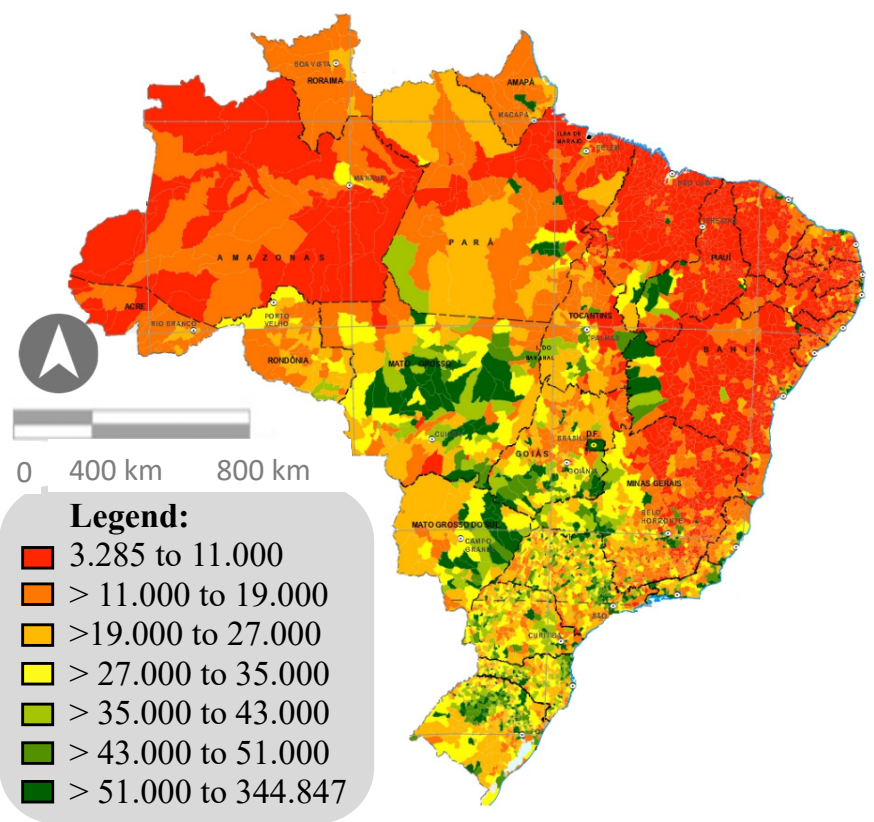

Source: Elaborated by the author based on the average municipal GDP per capita (IBGE, 2017).

When distributing the strategies geographically according to categories (Figure 5), some inferences may be made. A more homogeneous distribution of digital initiatives of health and education support occurs.

Health support (the results of which are distributed on map d) is, at this point in the pandemic situation, the most logical and critical area of action for municipal administrations. In this sense, the digital strategies adopted in the cities are associated with other measures which have already been used specifically by the medical sectors and front lines. More evident here is also the proximity between strategies of health support and the cities with a better history of adopting digital tools (Figure 5), which validates the analog-digital transposition in locations which already have some experience. The same occurs when observing the categories of initiatives on map (a), which denote the adaptation of services and several actions to the digital model.

In the case of education (map c), the high incidence of results, as well as their homogeneity, reflect the need for creating alternatives to the municipal school arrangement, maintaining social isolation nonetheless. Although literature, in general, does not deal enough with the educational element in the urban intelligence process, researchers such as Komninos (2011) and Caragliu, Del Bo, and Nijkamp (2011) consider that a city called smart acknowledges technological advancements and takes them on also for the need of disseminating knowledge, as is the case presented in the professional training processes and the virtualization of pedagogical practices. In an even wider perspective, the discussion allows for a closer proximity with the concept of collective intelligence of Lévy (2003), which advocates for a collective understanding which is increasingly improved after learning drawn from previous experiences and strategic validation (especially in the sense of anticipating demands, in accordance with the first postulated hypothesis). 


\section{FIGURE 5 RESULTS DISTRIBUTION BY CATEGORY}

(a)

(b)

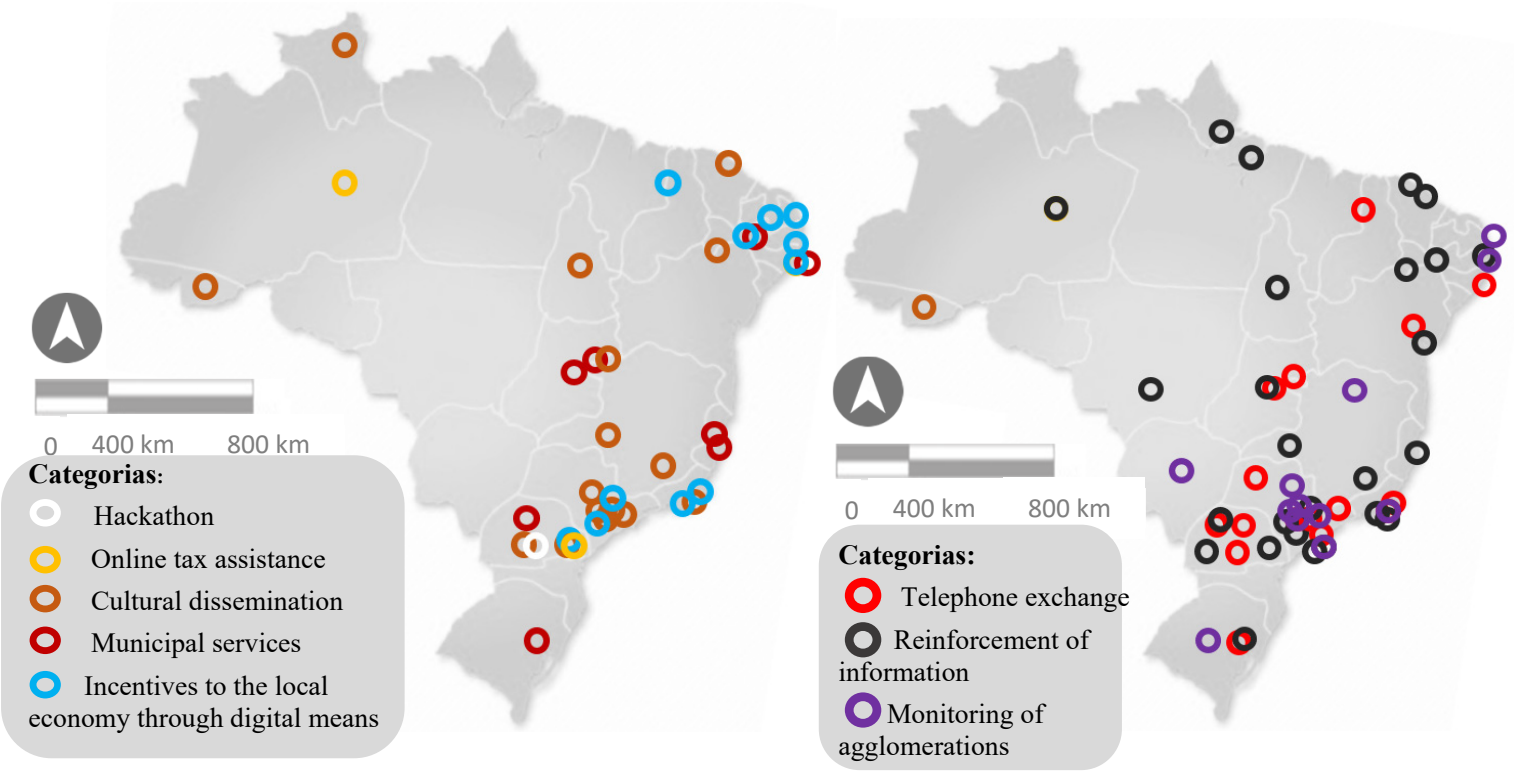

(c)

(d)

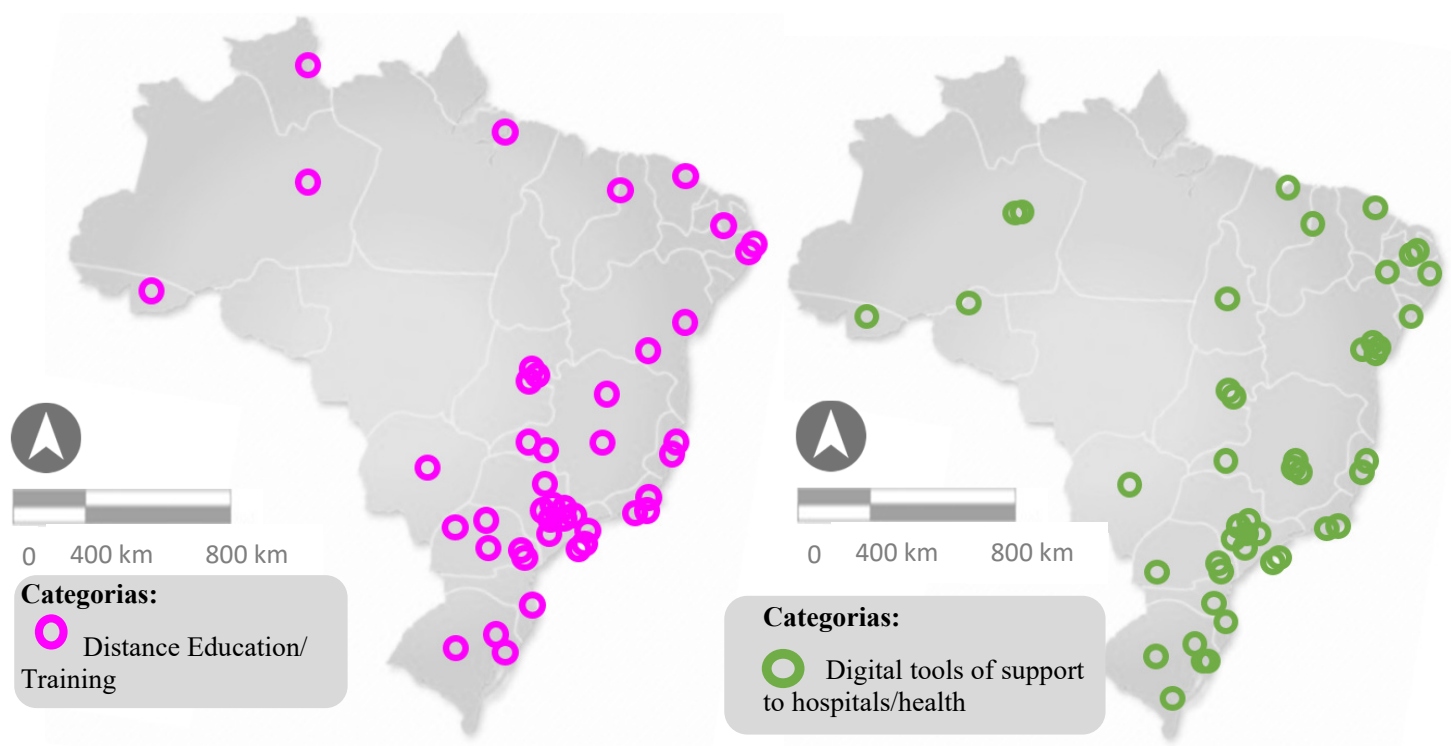

Source: Elaborated by the author.

Map (b) presents the categories relative to monitoring and disseminating information about the pandemic situation. The geographic distribution of strategies also follows the tendency of cities with a known history of digital use. Furthermore, these categories reflect one of the possibilities of communication action postulated by Oliver et al. (2020) aforementioned: situational awareness. 
Regarding other factors discussed by the same authors, some comments may be made: the issue of predictability may not be completely suggested just on the basis of the analyses presented here, since it is necessary to take into account the reality of each city and its respective capacity for adaptation and the tendencies of the locals already tested in the area - once more engendering the duality between what may be anticipating and what may be a mere emergency response. Concerning the cause and effect relationship and impact assessment factors, measurement may only be realized and validated fully in the future.

\section{FINAL CONSIDERATIONS}

This research investigated the digital strategies identified in Brazilian cities from the perspective of government monitoring or anticipation of the pandemic situation, or as a mere, mandatory and emergency response to the context. It was observed that the identified typologies partially follow the assumptions of Oliver et al. (2020) and Inn (2020) when mentioning the possibilities of adopting the digital in face of the crisis, especially regarding communication and adaptation to the virtual tooling. This suggests the surveyed Brazilian cities are following, to some degree, the tendencies of optimization and dealing that were adopted worldwide.

Nonetheless, the research points out there is a significant tendency of applying the strategies precisely where there is a facilitating context to this development: a higher GDP per capita or an already known history of innovative and digital instrumentation, which reinforces hypothesis $b$.

However, the discussion around the technological potential in cities must not be unilateral, considering technology as the last solution for demands. In this sense, it is presumed that the notion of smart city varies according to the context. Thus, intelligence is more strictly linked to adherence of the solution to local demands than the indiscriminate adoption of the technology. The true measurement of this process will only be possible in the future, after consolidation or fragmentation of the strategies analysed here is verified.

It is also worth reflecting that the evolution of the digital tooling, as well as the learning resulting from the crisis, raise the progressive awareness about the role of technology in the urban environment and about the community-governance relationship. This is part of the process of collective awareness, or the creation of a collective intelligence continuously developed from the learned lessons.

The research acknowledges the interim character of the results in its geographic-temporal frame and the significant variations that it may suffer quickly, especially in the current situation. In light of this, future studies will be necessary to validate tendencies, and to evaluate the continuity of public administrative actions which have taken the crisis as an opportunity for an increase in effectiveness. 


\section{REFERENCES}

Abella, A., Ortiz-de-Urbina-Criado, M., DePablos-Heredero, C. (2015, November/December). Information reuse in smart cities' ecosystems. El profesional de la información, 24(6), 838-844.

Albino, V., Berardi, U., \& Dangelico, R. M. (2015). Smart Cities: Definitions, Dimensions, Performance, and Initiatives. Journal of Urban Technology, 22(1), 3-21.

Aldairi, A. \& Tawalbeh, L. (2017). Cyber Security Attacks on Smart Cities and Associated Mobile Technologies. Procedia Computer Science, 109, 1086-1091. Retrieved from https://doi.org/10.1016/j. procs.2017.05.391

Amin, A. \& Thrift, N. (2002). Cities: reimagining the urban. New Jersey, NJ: Wiley.

Angelidou, M. (2014, July). Smart city policies: a spatial approach. Cities, 41(S1), S3-S11. Retrieved from https://doi.org/10.1016/j.cities.2014.06.007

Anthopoulos, L. (2017). Smart utopia VS smart reality: learning by experience from 10 smart city cases. Cities, 63, 128-148. Retrieved from https:// doi.org/10.1016/j.cities.2016.10.005

Barns, S. (2016). Mine your data: open data, digital strategies and entrepreneurial governance by code. Urban Geography, 37, 557-571.

Bibri, S. E., \& Krogstie, J. (2017). Smart sustainable cities of the future: an extensive interdisciplinary literature review. Sustainable Cities and Society, 31, 183-212.

Calvino, I. (2002). Le città invisibili. Milano, Italia: Oscar Mondadori.

Caragliu, A., Del Bo, C., \& Nijkamp, P. (2011). Smart Cities in Europe. Journal of Urban Technology, 18(2), 65-82.

Cassandras, C. G. (2016). Smart Cities as CyberPhysical Social Systems. Engineering, 2, 156-158.

Connected Smart Cities (2019). Ranking Connected Smart Cities 2019. Retrieved from https://www. connectedsmartcities.com.br/ranking-o-que-e/

Graham, S., \& Marvin, S. (1996). Telecommunications and the city: electronic spaces, urban places. London, UK: Routledge.
Inn, T. L. (2020, March 27). Smart City Technologies Take on COVID-19 (Penang Institute Issues: analysing Penang, Malasya and the region). Penang, Malásia: Penang Institute. Retrieved from https://penanginstitute.org/wp-content/ uploads/2020/04/27_03_2020_LII-INN.pdf

Instituto Brasileiro de Geografia e Estatística. (2017). PIB dos municípios: PIB per capita 2017. Rio de Janeiro, RJ: Autor. Retrieved from https://www.ibge. gov.br/apps/pibmunic/

Instituto Brasileiro de Geografia e Estatística. (2019). Estimativas de população 2019. Rio de Janeiro, RJ: Autor. Retrieved from https://www.ibge.gov.br/ estatisticas/sociais/populacao/9103-estimativas-depopulacao.html? =\&t=o-que-

Figueiredo, D. B., Filho, \& Silva, J. A., Jr. (2009). Desvendando os Mistérios do Coeficiente de Correlação de Pearson (r). Revista Política Hoje, 18(1), 115-146.

Komninos, N. (2011). Intelligent cities: variable geometries of spatial intelligence. Intelligent Buildings International, 3, 172-188.

Lemos, A. (2013). Cidades inteligentes: de que forma as novas tecnologias - como a computação em nuvem, o Big Data e a Internet das Coisas - podem melhorar a condição de vida nos espaços urbanos? Gvexecutivo, 12(2), 46-49.

Lévy, P. (2003). A inteligência coletiva: por uma antropologia do ciberespaço. (4. ed.). São Paulo, SP: Loyola.

Llacuna, M. M., Colomer-llinàs, J., \& MeléndezFrigola, J. (2015). Lessons in urban monitoring taken from sustainable and livable cities to better address the Smart Cities initiative. Technological Forecasting \& Social Change, 90, 611-622.

Ministério da Saúde. (2020). Coronavírus Brasil. Brasília, DF: Autor. Retrieved from https://covid. saude.gov.br/

Moraes, R. (1999). Análise de conteúdo. Revista Educação, 22(37), 7-32.

Oliver, N., Letouzé, E., Sterly, H., Delataille, S., De Nadai, M., Lepri, B. ... Vinck, P. (2020). Mobile phone data and COVID-19: Missing an opportunity? Ithaca, NY: Cornell University. Retrieved from https://arxiv. org/abs/2003.12347 
RAP | Smart cities and the pandemic: digital technologies on the urban management of Brazilian cities

Organização Mundial da Saúde. (2020). Nuevo Coronavirus 2019. Retrieved from https:// www.who.int/es/emergencies/diseases/novelcoronavirus-2019

Rolnik, R., \& Somekh, N. (2002). Governar as metrópoles: dilemas da recentralização. São Paulo em Perspectiva, 14(4), 83-90.

Sakellarides, C. (2020). From Viral City to Smart City: Learning from Pandemic Experiences. Acta
Médica Portuguesa, 33(6), 359-361. Retrieved from https://www.actamedicaportuguesa.com/revista/ index.php/amp/article/view/13841/5927

Salgado, M. M. (2016). A inteligência na sociedade positiva: dos humanos às cidades. In L. Santaella. (Org.), Cidades inteligentes: por que, para quem? (pp. 38-49). São Paulo, SP: Estação das Letras e Cores.

TrandingView. Coronavírus (COVID-19) gráficos e estatísticas. Retrieved from https://br.tradingview. com/covid19/

\section{Tharsila Maynardes Dallabona Fariniuk}

https://orcid.org/0000-0002-2283-0692

Ph.D. in Urban Management from the Postgraduate Program in Urban Management at the Pontifical Catholic University of Paraná (PUCPR); Postdoctoral researcher in Urban Management at the Pontifical Catholic University of Paraná (PUCPR); Professor of Architecture and Urbanism at the Unifacear University Center. E-mail: tharsilamd@gmail.com 